Производство мясопродуктов в Новосибирской области в 1980-е гг. (аналитическая записка облстатуправления)

DOI: 10.31518/2618-9100-2019-5-8

УДК 94(47)“1980”

Выходные данные для цитирования:

Ильиных В.А. Производство мясопродуктов в Новосибирской области в 1980-е гг. (аналитическая записка облстатуправления) // Исторический курьер. 2019. № 5 (7). C. 100-112. URL: http://istkurier.ru/data/2019/ISTKURIER-2019-508.pdf

\section{Meat production in Novosibirsk region \\ in 1980s (analytical note of regional department of statistics)}

\author{
DOI: 10.31518/2618-9100-2019-5-8
}

\section{How to cite:}

Il'inykh V.A. Meat production in Novosibirsk region in 1980s (analytical note of regional department of statistics) // Historical Courier, 2019, No 5 (7), pp. 100-112. [Available online:] http://istkurier.ru/ data/2019/ISTKURIER-2019-5-08.pdf

Abstract. The analytical note of the Novosibirsk regional department of statistics "On Production, procurement and provision of population with meat products" was identified in the funds of the Novosibirsk Regional State Archive. Its content is important for understanding of different features of agricultural development in the 1980s. The publication is accompanied by an introductory article, which contains an analysis of dynamics of agricultural production in Siberia from the second half of the 1960s to the 1980s. The pace of development of animal husbandry in the indicated period was higher than in the case of crop production. The increase in meat production was mainly provided by the precocious sub-sectors: poultry and pig farming. Despite the increase in meat production, it was impossible to satisfy the needs of population. Quality indicators for development of meat production remained low. Significant losses occurred during processing. One of the main causes of meat shortages in the 1980s was an increasing excess of solvent demand over supply.

Keywords: agricultural policy of the Soviet state; agriculture; husbandry; food program; Novosibirsk region.

The article has been received by the editor on 13.08.2019.

Full text of the article in Russian and references in English are available below.

Аннотация. В научный оборот вводится аналитическая записка Новосибирского облстатуправления «О производстве, заготовках и обеспечении населения мясными продуктами», выявленная в фондах Государственного архива Новосибирской области. Ее содержание имеет важное значение для понимания особенностей развития сельского хозяйства в 1980-е гг. Публикация предваряется вводной статьей, в которой проводится анализ динамики аграрного производства в Сибири во второй половине 1960-х - 1980-е гг. Темпы развития животноводства в указанный период были выше, чем растениеводства. Наращивание производства мяса в основном обеспечивалось за счет скороспелых подотраслей - птицеводства и свиноводства. Несмотря на увеличение производства мяса, удовлетворить потребности населения в нем не удалось. Низкими оставались качественные показатели развития отрасли. При переработке допускались значительные потери. Одной из основных причин дефицита мяса в 1980-е гг. было возрастающее превышение платежеспособного спроса над предложением.

\footnotetext{
* Ильиных Владимир Андреевич, доктор исторических наук, заведующий сектором аграрной истории Института истории Сибирского отделения Российской академии наук (Новосибирск, Россия), e-mail: agro_iwa@mail.ru

Ilinykh Vladimir A., Doctor of History Sciences, Head of the Department, Institute of History of the Siberian Branch of the Russian Academy of Science (Novosibirsk, Russia), e-mail: agro_iwa@mail.ru
} 
Ключевые слова: аграрная политика государства; сельское хозяйство; животноводство; продовольственная программа; Новосибирская область.

В Сибири в годы восьмой пятилетки (1966-1970 гг.) были достигнуты высокие темпы наращивания сельхозпроизводства. Валовое производство по сравнению с предыдущим пятилетием увеличилось в регионе в целом на 19,7\%, в Новосибирской области - на $21,8 \%{ }^{1}$. Этому, безусловно, способствовали меры по экономическому стимулированию сельхозпредприятий и сельских тружеников, а также увеличение капитальных вложений. Но эффект от предпринятых мер был усилен благодаря более благоприятным, чем в предыдущее пятилетие, погодно-климатическими условиям.

В 1970-е гг. темпы прироста аграрного производства начали снижаться. В годы девятой пятилетки (1971-1975 гг.) валовая продукция сельского хозяйства в Сибири и Новосибирской области увеличилась на 11 и 13,6\% соответственно, в годы десятой пятилетки (1976-1980 гг.) - на 2,3 и 0,6\%. Значительное влияние на темпы развития аграрного сектора экономики региона во второй половине 1970-х гг. оказали погодноклиматические условия. Годы десятой пятилетки оказались существенно менее урожайными, чем предыдущей. Одиннадцатая пятилетка (1981-1985 гг.) началась с двух подряд катастрофических неурожаев на большей части Западной Сибири, включая юг Новосибирской области. В Сибири в целом за 1981-1982 гг. объем аграрного производства сократился на $6,2 \%{ }^{2}$.

Снижение темпов развития сельского хозяйства происходило в условиях нарастания кризисных явлений в отрасли. Резко упали эффективность сельхозпроизводства, его фондоотдача, окупаемость применяемых средств, производительность труда, возросла себестоимость продукции. Главным сдерживающим фактором роста производства являлась низкая трудовая отдача работников сельхозпредприятий. Колхозники и рабочие совхозов, трудившиеся в громоздких и трудноуправляемых подразделениях, не были связаны с конечным результатом ни организационно, ни материально. Деньги они получали за выход на работу, а не за ее итоги. А основная трудовая функция сводилась к механистичному (почти как на заводском конвейере) выполнению операций сельскохозяйственного цикла. Нарастающее отчуждение от средств производства и результатов труда приводило к ослаблению трудовой, исполнительской и технологической дисциплины, нерациональному расходованию сырья, материалов, электроэнергии. Потребительский спрос на ценные продукты питания опережал предложение. Особенно масштабным и общественно значимым был дефицит мяса и мясопродуктов. В связи с этим началась реанимация карточной системы.

Кризисные явления в разной степени затронули отдельные отрасли и подотрасли аграрного сектора экономики. В 1981-1985 гг. среднегодовое производство яиц, мяса, молока и зерна в регионе в целом выросло по сравнению с 1966-1970 гг. соответственно на $131,32,4,9,3$ и 0,6 \%, в Новосибирской области - на 154, 29,4, 4,1 и 7,4 \%. В Сибири валовая продукция животноводства за годы десятой пятилетки увеличилась на 5,9 \%, одиннадцатой пятилетки - на 6 \%, в Новосибирской области - на 5,2 и 3,9 \%. В растениеводстве во второй

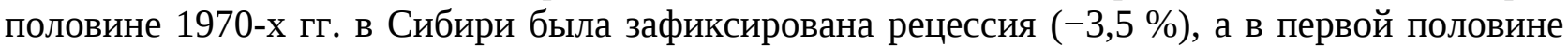
1980-х гг. - незначительный рост (+2,8 \%). В Новосибирской области спад продолжался две пятилетки подряд: $-6,7$ и $-3,2 \%$.

В животноводстве постоянно возрастала роль скороспелых подотраслей - птицеводства и свиноводства, производство продукции которых все больше перемещалось на крупные

\footnotetext{
${ }^{1}$ Здесь и далее, кроме особо оговоренных случаев, количественные параметры аграрного производства рассчитаны по статистическим сборникам ЦСУ СССР и Госкомстата СССР, РСФСР и РФ: Сельское хозяйство СССР (1965-1981 гг.). М., 1982; Сельское хозяйство СССР. М., 1988; Развитие агропромышленного комплекса РСФСР. М., 1989; Сельское хозяйство в России. М., 1998; Российский статистический ежегодник. 2000. M., 2000.

${ }^{2}$ Крестьянство и сельское хозяйство Сибири. 1960-1980-е гг. Новосибирск, 1999. С. 151.
} 
птицефабрики и свинокомплексы. В то же время темпы развития молочного скотоводства были низкими. Необходимость налаживания стабильного кормообеспечения животноводческих комплексов и птицефабрик определяла расширение посевов кормовых и зерновых фуражных культур. Площади, занятые пшеницей, напротив, сокращались.

Обстановка, сложившаяся в сельском хозяйстве СССР к началу 1980-х гг., требовала принятия мер, способствующих ускорению темпов аграрного производства. На это была направлена принятая майским (1982 г.) пленумом ЦК КПСС Продовольственная программа, рассчитанная до 1990 г. $^{3}$ В качестве основных методов достижения поставленных в ней целей, предлагались вполне традиционные: наращивание капиталовложений, техническое перевооружение, увеличение масштабов химизации и мелиорации, внедрение достижений сельскохозяйственной науки и передового опыта. Принципиальной новацией Продовольственной программы была ставка на внедрение «прогрессивных форм» организации производства и стимулирования труда работников сельхозпредприятий (коллективного подряда).

Распространение коллективного подряда, введение в эксплуатацию крупных птицефабрик и животноводческих комплексов, а также более благоприятные, чем в начале 1980-х гг., погодные условия позволили уже в середине десятилетия улучшить ситуацию в сельском хозяйстве Сибири. Несмотря на рецессию 1981-1982 гг., валовое производство сельхозпродукции в регионе в целом выросло за одиннадцатую пятилетку на 5,6 \%, в Новосибирской области - на 1,3\%. Во второй половине десятилетия темпы наращивания сельхозпроизводства продолжали увеличиваться. Среднегодовое валовое производство аграрной продукции в Сибири за годы двенадцатой пятилетки (1986-1990 гг.) выросло на 11,8, в Новосибирской области - на 12\%. В 1986-1990 гг. среднегодовой прирост производства мяса, яиц, молока и зерна в Сибири составил соответственно 18,1, 11,5, 13,9 и 4,3 \%, в Новосибирской области - 21,2, 1,9, 6,4 и 7,6 \%.

Последняя советская пятилетка оказалась для сельского хозяйства региона достаточно результативной. Более высокие темпы его роста в регионе за предыдущее тридцатилетие были достигнуты лишь за годы восьмой пятилетки. При этом следует иметь в виду, что в первой половине 1960-х гг. в сельском хозяйстве был зафиксирован значительный спад, связанный с неурожаями 1962, 1963 и 1965 гг. в целинных районах. Поэтому высокие темпы развития сельского хозяйства в годы восьмой пятилетки имели в значительной степени компенсаторный, восстановительный характер.

Несмотря на позитивные структурные и количественные изменения, принципиальных качественных сдвигов в аграрном секторе экономики не произошло. Качество производимой продукции оставалось низким, уровень потерь- высоким, переработка продукции недостаточной и несовершенной. Прирост объема производства сельхозпродукции не компенсировал растущее превышение платежеспособного спроса населения на продукты питания над их предложением. Продовольственное снабжение населения продолжало ухудшаться, карточная система приобрела тотальный характер, что способствовало радикализации общественного сознания и, в конечном итоге, привело к смене политической и экономической системы, включая аграрный строй.

Ниже в соответствии с существующими правилами публикуется аналитическая записка Новосибирского облстатуправления «О производстве, заготовках и обеспечении населения мясными продуктами», выявленная в фонде Р-11 (Новосибирское областное управление статистики Государственного комитета РСФСР по статистике) Государственного архива Новосибирской области.

В Записке сообщается, что среднегодовое производство мяса в области в 1986-1988 г. увеличилось по сравнению с 1981-1985 гг. на $18 \%$. Наиболее высокими темпами наращивалось производство мяса птицы (+52\%) и свинины (+22\%), в то время как говядины произвели на $8 \%$, а баранины - на $4 \%$ больше. Выросла обеспеченность населения мясопродуктами. Несмотря на достигнутый прирост производства, задания

\footnotetext{
${ }^{3}$ КПСС в резолюциях и решениях съездов, конференций и пленумов ЦК. 9-е изд. М., 1987. Т. 14. С. $276-314$.
} 
Продовольственной программы по их выпуску выполнить не удалось. Низкими оставались качественные показатели развития отрасли. При переработке продукции допускались значительные потери. Дефицит мяса сохранялся. Одной из его основных причин было продолжающее увеличиваться превышение платежеспособного спроса населения над предложением.

\section{Аналитическая записка Новосибирского областного управления статистики «О производстве, заготовках и обеспечении населения мясными продуктами»}

г. Новосибирск

30 ноября 1989 г.

1. Обком КПСС т. Мухе В.П. [1]

2. Облисполком т. Бокову В.А. [2]

3. Госкомстат РСФСР - 11

О производстве, заготовках и обеспечении населения мясными продуктами

В текущей пятилетке несколько улучшилось снабжение населения мясными продуктами. В промышленности наблюдается рост выработки мяса, колбасных изделий, консервов мясных. Выросла поставка мяса и мясопродуктов по рыночному фонду из государственных ресурсов. Увеличился фонд потребления населения мяса и мясных продуктов. Потребление их на душу населения в 1988 году по сравнению с 1985 годом увеличилось на 9 процентов (из нормированного снабжения выведено мясо птицы). Однако проблема обеспечения населения мясопродуктами остается напряженной, несмотря на позитивные сдвиги в развитии животноводства.

Наращивание производства мяса идет во всех категориях хозяйств, но более высокими темпами - в личных подсобных хозяйствах населения, что видно из нижеприведенных данных:

(в убойном весе, тыс. тонн)

\begin{tabular}{|c|c|c|c|c|c|c|c|}
\hline & $\begin{array}{c}\text { 1981-1985 гг. } \\
\text { (в среднем } \\
\text { за год) }\end{array}$ & $\begin{array}{c}\text { 1986-1988 гг. } \\
\text { (в среднем } \\
\text { за год) }\end{array}$ & 1986 г. & 1987 г. & 1988 г. & $\begin{array}{c}1986-1988 \text { гг. } \\
\text { в \% к 1981- } \\
1985 \text { гг. }\end{array}$ & $\begin{array}{c}1988 \text { г. в \% } \\
\text { к } 1987 \text { г. }\end{array}$ \\
\hline $\begin{array}{l}\text { Все категории } \\
\text { хозяйств }\end{array}$ & 189,7 & 223,2 & 216,6 & 229,7 & 223,2 & 118 & 97 \\
\hline \multicolumn{8}{|l|}{ в том числе: } \\
\hline $\begin{array}{l}\text { колхозы и } \\
\text { госхозяйства }\end{array}$ & 135,8 & 157,6 & 152,6 & 161,6 & 158,7 & 116 & 98 \\
\hline \multicolumn{8}{|l|}{ из них: } \\
\hline колхозы & 22,0 & 24,5 & 24,1 & 25,5 & 23,9 & 111 & 94 \\
\hline совхозы & 103,9 & 123,3 & 117,6 & 127,5 & 124,9 & 119 & 98 \\
\hline $\begin{array}{l}\text { личные } \\
\text { подсобные } \\
\text { хозяйства } \\
\text { населения }\end{array}$ & 53,9 & 65,5 & 64,2 & 68,1 & 64,5 & 122 & 95 \\
\hline
\end{tabular}

Несмотря на увеличение производства, отставание, допущенное в начале одиннадцатой пятилетки, не позволяет выйти на рубежи, намеченные Продовольственной программой [3].

К 1990 году предусматривалось произвести (в убойном весе) 255,3 тысячи тонн мяса, в том числе 150,3 тысячи тонн говядины, 63,7 тысячи тонн свинины, 9,7 тысячи тонн баранины и козлятины, 29,2 тысячи тонн мяса птицы. Ежегодный прирост производства говядины в двенадцатой пятилетке должен составлять 6 , свинины- 4,4, баранины и козлятины - 1,3 процента. Фактически в 1988 году производство свинины увеличилось на 2, баранины и козлятины - на 15 процентов, а говядины - даже сократилось на 8 процентов. 
В структуре производства мяса опережающими темпами росло производство мяса птицы и свинины, что видно из следующих данных:

(во всех категориях хозяйств, в убойном весе, тысяч тонн)

\begin{tabular}{|l|c|c|c|c|c|c|c|}
\hline & $\begin{array}{c}1981-1985 \text { гг. } \\
\text { (в среднем } \\
\text { за год) }\end{array}$ & $\begin{array}{c}1986-1988 \text { гг. } \\
\text { (в среднем } \\
\text { за год) }\end{array}$ & 1986 г. & 1987 г. & 1988 г. & $\begin{array}{c}1986-1988 \text { гг. } \\
\text { в \% к 1981- } \\
1985 \text { гг. }\end{array}$ & $\begin{array}{c}1988 \text { г. в \% } \\
\text { к 1987 г. }\end{array}$ \\
\hline Говядина & 107,0 & 115,8 & 114,1 & 121,2 & 112,1 & 108 & 98 \\
\hline Свинина & 48,1 & 58,5 & 57,0 & 58,5 & 59,9 & 122 & 105 \\
\hline $\begin{array}{l}\text { Баранина и } \\
\text { козлятина }\end{array}$ & 8,0 & 8,3 & 7,7 & 8,0 & 9,1 & 104 & 118 \\
\hline Мясо птицы & 24,6 & 37,5 & 35,2 & 38,4 & 38,8 & 152 & 110 \\
\hline
\end{tabular}

В общем объеме производства мяса удельный вес говядины за последние три года не превышал 53, свинины - 27 процентов.

Значительно выше удельный вес говядины в производстве мяса в Карасукском, Доволенском, Усть-Таркском, Чановском, Барабинском и Здвинском районах, свинины Северном, Новосибирском, Мошковском районах.

Большие возможности в увеличении ресурсов мяса заложены в улучшении качественных кондиций скота. Однако они используются далеко не в полной мере.

(колхозы, совхозы, межхозяйственные предприятия)

\begin{tabular}{|c|c|c|c|c|c|c|}
\hline \multirow{3}{*}{ Годы } & \multicolumn{3}{|c|}{ Крупный рогатый скот } & \multicolumn{3}{|c|}{ Свиньи } \\
\hline & \multicolumn{2}{|c|}{ средний вес скота, кг } & \multirow{2}{*}{$\begin{array}{c}\text { среднесуточный } \\
\text { привес на } \\
\text { откорме, граммов }\end{array}$} & \multicolumn{2}{|c|}{ средний вес скота, кг } & \multirow{2}{*}{$\begin{array}{c}\text { среднесуточный } \\
\text { привес на } \\
\text { откорме, граммов }\end{array}$} \\
\hline & $\begin{array}{c}\text { поставленного } \\
\text { на откорм }\end{array}$ & $\begin{array}{l}\text { снятого с } \\
\text { откорма }\end{array}$ & & $\begin{array}{c}\text { поставленного } \\
\text { на откорм }\end{array}$ & $\begin{array}{l}\text { снятого с } \\
\text { откорма }\end{array}$ & \\
\hline 1985 г. & 287 & 381 & 492 & 41 & 97 & 432 \\
\hline 1986 г. & 291 & 384 & 520 & 42 & 108 & 458 \\
\hline 1987 г. & 290 & 383 & 495 & 43 & 104 & 455 \\
\hline 1988 г. & 287 & 379 & 536 & 50 & 108 & 461 \\
\hline
\end{tabular}

Более высокие привесы крупного рогатого скота на откорме и нагуле получают хозяйства Болотнинского (718), Новосибирского (682), Ордынского (669), Колыванского (635) районов; свиней - Новосибирского (533), Сузунского (463), Барабинского (460) районов. Менее 400 граммов они в хозяйствах Чистоозерного и Убинского районов, что говорит о серьезных недостатках в организации откорма. Низкие привесы свиней на откорме имеют хозяйства Венгеровского (118), Купинского (124), Кочковского (160) районов.

Увеличение производства кормов при улучшении качества - одно из решающих требований наращивания производства животноводческой продукции. Однако планы заготовки грубых и сочных кормов не выполняются. В расчете на одну условную голову крупного скота заготавливаются в общественном секторе не более 17 центнеров кормов (в перерасчете на кормовые единицы):

\begin{tabular}{|l|c|c|}
\hline \multirow{2}{*}{\multicolumn{2}{|c|}{ Годы }} & \multicolumn{2}{|c|}{ Заготовлено грубых и сочных кормов (в кормовых единицах) } \\
\cline { 2 - 3 } & Всего, тысяч тонн & $\begin{array}{c}\text { В расчете на одну условную голову } \\
\text { крупного скота, центнеров }\end{array}$ \\
\hline $1981-1985$ (в среднем за год) & 1861 & 15,0 \\
\hline 1986 & 2165 & 17,2 \\
\hline 1987 & 1904 & 15,1 \\
\hline 1988 & 2045 & 16,3 \\
\hline
\end{tabular}


Качество кормов улучшается слабо. Остается высоким удельный вес низкокачественных кормов. В 1988 году по сену и сенажу он составил 51, силосу - 37, травяной муке искусственной сушки - 60 процентов.

Большие резервы увеличения производства мяса заложены в сокращении падежа продуктивных животных, улучшении использования маточного поголовья.

Хозяйства ежегодно несут большие потери продукции от падежа и гибели животных. Высоким остается падеж скота и в текущем году:

(в колхозах, совхозах и межхозяйственных предприятиях)

\begin{tabular}{|l|c|c|c|c|}
\hline & 1985 г. & 1986 г. & 1987 г. & 1988 г. \\
\hline Пало и погибло, тысяч голов & & & & \\
\hline крупного рогатого скота & 103,8 & 86,0 & 88,5 & 76,2 \\
\hline свиней & 78,7 & 80,9 & 70,2 & 65,9 \\
\hline овец и коз & 116,4 & 109,3 & 128,7 & 107,4 \\
\hline В \% к обороту стада & & & & \\
\hline крупного рогатого скота & 5,1 & 4,3 & 4,6 & 4,0 \\
\hline свиней & 8,1 & 8,1 & 6,6 & 6,0 \\
\hline овец и коз & 9,7 & 8,9 & 10,4 & 9,0 \\
\hline
\end{tabular}

Потери мяса от падежа и гибели животных в 1988 году составили около 38 тысяч тонн, или 11 процентов от общего производства.

Низкая сохранность крупного рогатого скота в хозяйствах Усть-Таркского, Чановского, Убинского районов (5,6 \% к обороту стада). Потери от падежа в этих районах составили более 4 тысяч тонн.

Большое количество свиней пало в Татарском $(10,4$ \% к обороту стада), Ордынском $(9,9)$, Мошковском $(9,4)$ районах.

Потери составили соответственно 270, 716 и 751 тонну.

В хозяйствах области ежегодно погибает большое количество молодняка. Так, в 1988 году пало и погибло 48,4 тыс. телят (10,1 \% к приплоду), 51,1 тысячи поросят (7,9%), 36,9 тысячи ягнят (12,4 \%).

Наиболее высокий процент падежа молодняка крупного рогатого скота имели хозяйства: Кочковского (14,8 \%), Кыштовского (14,6 \%), Усть-Таркского $(14,4 \%)$, Карасукского и Чистоозерного (14,1\%) районов; молодняка свиней - Мошковского (14\%), Коченевского $(13,6 \%)$, Болотнинского $(12,4)$ районов.

Хозяйства ежегодно недополучают значительное количество телят, поросят, ягнят из-за упущений в работе с воспроизводством стада:

(в колхозах, совхозах и межхозяйственных предприятиях)

\begin{tabular}{|l|c|c|c|c|}
\hline & 1985 г. & 1986 г. & 1987 г. & 1988 г. \\
\hline Получено телят - тысяч голов & 475,6 & 494,7 & 499,4 & 477,2 \\
\hline на 100 коров & 79 & 82 & 81 & 81 \\
\hline Получено поросят - тысяч голов & 579,3 & 892,9 & 650,6 & 646,2 \\
\hline на 100 основных свиноматок & 1668 & 1863 & 1791 & 1759 \\
\hline Получено ягнят - тысяч голов & 318,9 & 314,9 & 318,2 & 298,2 \\
\hline на 100 овцематок & 77 & 77 & 77 & 74 \\
\hline
\end{tabular}

Из-за яловости [4] хозяйства недополучили в 1988 году 88 тысяч телят. Потери мяса (по расчетам) составили 18,9 тысячи тонн, которыми можно обеспечить 266 тысяч человек в течение года. 
Растет число хозяйств, снижающих выход приплода на 100 маток, что видно из данных приведенной группировки:

\begin{tabular}{|l|c|c|c|c|c|c|}
\hline \multirow{2}{*}{ Годы } & \multicolumn{6}{|c|}{ Количество хозяйств с выходом телят на 100 коров } \\
\cline { 2 - 7 } & до 70 & $70-79$ & $80-84$ & $85-89$ & $90-94$ & 95 и более \\
\hline 1981 & 21 & 98 & 97 & 85 & 88 & 56 \\
\hline 1985 & 73 & 137 & 99 & 81 & 44 & 42 \\
\hline 1986 & 38 & 119 & 116 & 92 & 58 & 56 \\
\hline 1987 & 56 & 122 & 104 & 79 & 78 & 43 \\
\hline 1988 & 59 & 146 & 103 & 71 & 66 & 38 \\
\hline
\end{tabular}

Низкий выход телят на 100 коров в 1988 году имели хозяйства Усть-Таркского (69), Венгеровского, Кыштовского, Искитимского (76) районов; поросят на 100 основных свиноматок - хозяйства Кочковского (505), Кыштовского (866), Северного (892), Краснозерского (952), Каргатского (964) районов; ягнят на 100 овцематок - хозяйства Каргатского (60), Венгеровского (63), Кочковского, Куйбышевского (64) районов.

Одним из путей увеличения производства мяса является развитие личных подсобных хозяйств населения. По сравнению с 1981-1985 гг. среднегодовое производство мяса за прошедшие годы текущей пятилетки в личных подсобных хозяйствах населения увеличилось на 11,6 тысячи тонн (22 \%).

Производство мяса в личных подсобных хозяйствах населения в расчете на одного сельского жителя увеличилось за этот период с 74 до 92 килограммов.

Выше среднеобластного уровня этот показатель в Маслянинском районе - 133, Каргатском - 132, Чулымском - 127 килограммов.

Менее всего в расчете на одного сельского жителя производится мяса личными подсобными хозяйствами Новосибирского района - 34, Баганского - 61, Мошковского - 64 килограмма.

Рост производства мяса в личных подсобных хозяйствах населения тесно связан с ростом продажи поросят и молодняка птицы колхозами, госхозами и инкубаторно-птицеводческими станциями хозяйствам населения, т.к. поголовье скота у населения сокращается. На начало года в хозяйствах населения насчитывалось 285,1 тысячи голов крупного рогатого скота, 138,4 тысячи коров, 146,2 тысячи свиней, 475,4 тысячи овец и коз против соответственно 293,6, 136,1, 158,7, 529,8 тысячи голов на начало 1986 года.

Сократилось поголовье крупного рогатого скота в текущей пятилетке в личных подсобных хозяйствах населения - 24, коров - 21, свиней -25 , овец и коз - 27 районов области.

Наибольшее сокращение поголовья крупного рогатого скота допустили хозяйства Новосибирского (на $13 \%$ ), Кыштовского на $12 \%$ ) районов, коров - Венгеровского, Северного, Болотнинского (на $8 \%$ ) районов, свиней - Новосибирского (на 39 \%), Краснозерского (на $28 \%$ ), Кочковского (на 26\%) районов, овец и коз - Чулымского (на $22 \%$ ), Татарского (на 20 \%) районов.

В области большое количество хозяйств населения не имеет скота, что видно из следующей таблицы:

(на 1 января, тысяч хозяйств)

\begin{tabular}{|l|c|c|c|c|}
\hline & 1986 г. & 1987 г. & 1988 г. & 1989 г. \\
\hline Количество хозяйств, не имеющих всех видов скота & 40,4 & 42,1 & 44,8 & 43,5 \\
\hline в процентах к общему числу хозяйств & 24,5 & 25,6 & 27,3 & 26,4 \\
\hline в том числе: & & & & \\
\hline крупного рогатого скота & 58,3 & 57,8 & 57,4 & 56,1 \\
\hline
\end{tabular}




\begin{tabular}{|l|c|c|c|c|}
\hline в процентах к общему числу хозяйств & 35,4 & 35,2 & 35,0 & 34,1 \\
\hline коров & 63,7 & 64,1 & 65,0 & 64,1 \\
\hline в процентах к общему числу хозяйств & 38,7 & 39,0 & 39,6 & 38,9 \\
\hline свиней & 91,1 & 91,1 & 91,7 & 96,4 \\
\hline в процентах к общему числу хозяйств & 55,4 & 55,5 & 55,8 & 58,6 \\
\hline овец & 88,9 & 88,6 & 90,5 & 89,9 \\
\hline в процентах к общему числу хозяйств & 54,0 & 53,9 & 55,1 & 54,6 \\
\hline коз & 122,8 & 118,7 & 123,0 & 122,2 \\
\hline в процентах к общему числу хозяйств & 74,6 & 72,2 & 74,9 & 74,2 \\
\hline
\end{tabular}

В 1988 году несколько сократилось число хозяйств, не имеющих скота. При этом количество хозяйств, не имеющих свиней, возросло, несмотря на рост продажи поросят населению (на 33,2 тысячи голов против 1985 года).

Подсобные сельские хозяйства предприятий, учреждений и организаций [5] в общем объеме производства мяса общественным сектором занимают незначительный удельный вес - 1,9 процента.

По сравнению с 1985 годом производство мяса в подсобных хозяйствах увеличилось в 2,3 раза и составило 3,1 тысячи тонн (в убойном весе).

В ряде предприятий продукция подсобных хозяйств стала существенным подспорьем в улучшении снабжения работников мясными продуктами.

Лучшие показатели в расчете на одного работника в 1988 году имели Жуланский маслозавод (40,7 кг), Электродный завод (12,8 кг), «Тяжстанкогидропресс» $(12,5)$.

В то же время подсобное хозяйство «Сибэнерго» произвело лишь 2,6 килограмма в расчете на одного работника, Казаче-Мысского маслозавода - 7,6 килограмма.

Рост производства мяса определил темпы роста закупок скота и птицы.

Среднегодовые закупки скота и птицы в текущей пятилетке в хозяйствах всех категорий по сравнению с 1981-1985 гг. увеличились на 14 процентов и составили 222,8 тысячи тонн. В 1988 году закуплено 234,8 тысячи тонн скота и птицы, на 6,9 процента, или 15,3 тысячи тонн, больше чем в 1987 году.

Объемы государственных закупок скота и птицы изменились следующим образом:

(тыс. тонн)

\begin{tabular}{|c|c|c|c|}
\hline & \multirow{2}{*}{$\begin{array}{c}\text { Все категории } \\
\text { хозяйств }\end{array}$} & \multicolumn{2}{|c|}{ В том числе } \\
\hline & & $\begin{array}{c}\text { колхозы, совхозы и др. } \\
\text { госхозяйства }\end{array}$ & $\begin{array}{c}\text { личные подсобные } \\
\text { хозяйства населения }\end{array}$ \\
\hline 1981-1985 гг. (в среднем за год) & 196,1 & 195,8 & 0,3 \\
\hline 1986-1988 г. (в среднем за год) & 222,8 & 220,3 & 2,5 \\
\hline 1986 г. & 214,2 & 211,1 & 3,1 \\
\hline 1987 г. & 219,5 & 217,8 & 1,4 \\
\hline 1988 г. & 234,8 & 231,9 & 2,9 \\
\hline Январь-август 1989 г. & 164,5 & - & - \\
\hline Январь-август 1988 г. & 139,8 & - & - \\
\hline 1989 г. в \% к 1988 г. & 118 & - & - \\
\hline
\end{tabular}

* с учетом закупок по договорам у населения

Закупки скота и птицы в 1986-1988 гг. по сравнению со среднегодовыми в одиннадцатой пятилетке сократились в Северном (на $6 \%$ ), Куйбышевском (2\%), Здвинском (0,2 \%) и 
Чулымском (6 \%) районах. Возросли они в Новосибирском районе на 24, Сузунском - на 21, Тогучинском - на 19 процентов.

Выполнение планов по общему объему закупок скота и птицы характеризуется следующими данными:

(в процентах)

\begin{tabular}{|l|c|c|}
\hline & Все категории хозяйств & $\begin{array}{c}\text { В том числе колхозы, совхозы } \\
\text { и другие госпредприятия }\end{array}$ \\
\hline $1981-1985$ гг. & 93,2 & 93,2 \\
\hline $1986-1988$ г. & 102,6 & 101,9 \\
\hline 1986 г. & 100,5 & 99,0 \\
\hline 1987 г. & 101,8 & 101,7 \\
\hline 1988 г. & 105,5 & 105,0 \\
\hline Январь-август 1989 г. & $61^{*}$ & - \\
\hline
\end{tabular}

*к годовому плану

Не справились с планом закупок скота и птицы 1988 года хозяйства 8 районов, в том числе: Куйбышевского - на 12 процентов, Татарского - на 10, Северного - на 7 процентов.

В текущем году более высокие показатели имеют хозяйства Колыванского (75 \%), Карасукского (72 \%), Кочковского (71\%), Доволенского, Искитимского, Болотнинского (70 \%) районов.

Менее 50 процентов к годовому плану закупок поступило скота и птицы от хозяйств Чулымского, Чистоозерного, Убинского районов.

Количество колхозов и совхозов, не справившихся с выполнением планов закупок скота и птицы, в последние годы снижалось, что видно из следующих данных:

\begin{tabular}{|l|c|}
\hline \multicolumn{1}{|c|}{ Годы } & $\begin{array}{c}\text { Доля хозяйств, не выполнивших план } \\
\text { (в \% к общему числу хозяйств, имевших план) }\end{array}$ \\
\hline 1981 & 39 \\
\hline 1982 & 56 \\
\hline 1983 & 39 \\
\hline 1984 & 45 \\
\hline 1985 & 43 \\
\hline 1986 & 29 \\
\hline 1987 & 25 \\
\hline 1988 & 23 \\
\hline
\end{tabular}

В 1988 году этими хозяйствами недодано к плану 7,5 тысячи тонн, в 1981 году - 15,8 тысячи тонн скота и птицы.

В предыдущем году наибольшее количество таких хозяйств насчитывалось в Татарском (76 \%), Куйбышевском (63 \%), Северном (42 \%) районах. Ими недопоставлено в госресурсы более 2 тысяч тонн скота и птицы.

Всего за 3 года текущей пятилетки такими хозяйствами недодано 294 тысячи тонн, за одиннадцатую пятилетку - 115,7 тысячи тонн скота и птицы.

Важным резервом увеличения объемов государственных закупок скота и птицы является привлечение продукции личных подсобных хозяйств населения.

За 1986-1988 гг. в личных подсобных хозяйствах населения (с учетом продукции, закупленной колхозами и совхозами у населения по договорам) заготовлено 7,5 тысячи тонн скота и птицы (1,1 процента от общего объема закупок). 
Организациями потребительской кооперации закуплено в 1988 году по договорам у населения 2405 тонн скота и птицы, в том числе в выполнение плана колхозами и совхозами засчитана 1971 тонна.

Средний вес крупного рогатого скота, проданного государству в текущей пятилетке, по сравнению с предыдущей повысился на 10, свиней - на 8, овец - на 4 килограмма.

\begin{tabular}{|l|c|c|c|}
\hline \multirow{2}{*}{ Годы } & \multicolumn{3}{|c|}{ Средний вес одной головы скота, проданного государству, кг } \\
\cline { 2 - 4 } & крупного рогатого скота & свиней & овец \\
\hline 1981 & 370 & 104 & 35 \\
\hline 1982 & 343 & 96 & 33 \\
\hline 1983 & 344 & 101 & 35 \\
\hline 1984 & 388 & 103 & 36 \\
\hline 1985 & 360 & 100 & 36 \\
\hline 1986 & 367 & 110 & 36 \\
\hline 1987 & 369 & 107 & 40 \\
\hline 1988 & 367 & 108 & 40 \\
\hline
\end{tabular}

"с учетом привеса реализованного откормочными хозяйствами

По сравнению с 1985 годом в 1988 году продавали государству крупный рогатый скот пониженным весом хозяйства Доволенского (на 14 кг), Каргатского (на 13 кг), Чулымского (на 10 кг), Венгеровского (на 7 кг) районов.

Средний вес одной головы свиней, проданных государству за этот период, снизился на 82 килограмма в хозяйствах Здвинского, на 50 - Чановского, на 33 - Усть-Таркского районов.

Несмотря на рост в 1988 году против 1985 года доли скота высшей категории упитанности, сданного государству, с 52 до 56 процентов, удельный вес скота ниже средней упитанности и тощего снизился только на один пункт. Ежегодно такого скота поступает в госресурсы более 20 процентов.

В предыдущем году поступило в госресурсы крупного рогатого скота низких весовых кондиций в Чановском районе - 31, Татарском - 30, Усть-Таркском - 29, Купинском, Кыштовском и Чулымском - 28 процентов.

Нестандартных свиней сдано государству 3 процента от общего объема их закупок. В хозяйствах Баганского района доля таких свиней составила 47, Доволенского - 32, Мошковского - 14, Черепановского - 7 процентов.

Более половины произведенного мяса поступает на переработку на мясокомбинаты области. Область занимает 17[-е] место в РСФСР по переработке мяса.

\begin{tabular}{|c|c|c|c|c|c|}
\hline & \multicolumn{2}{|c|}{$\begin{array}{c}\text { Среднегодовое } \\
\text { производство за }\end{array}$} & \multirow{2}{*}{$\begin{array}{c}\text { Темпы } \\
\text { роста } \\
\text { в \% }\end{array}$} & \multirow{2}{*}{$\begin{array}{c}\text { Произведено } \\
\text { за } 8 \text { месяцев } \\
1989 \text { г. }\end{array}$} & \multirow{2}{*}{$\begin{array}{c}\text { В \% к } \\
\text { соотвест[вующему] } \\
\text { периоду прошл[ого] } \\
\text { года }\end{array}$} \\
\hline & 1981-1985 гг. & 1986-1988 гг. & & & \\
\hline $\begin{array}{l}\text { Мясо, включая } \\
\text { субпродукты } \\
\text { I категории, тыс. } \\
\text { тонн } \\
\end{array}$ & 110,3 & 125,8 & 114,1 & 82,7 & 109,9 \\
\hline $\begin{array}{l}\text { Колбасные } \\
\text { изделия, тысяч } \\
\text { тонн }\end{array}$ & 27,0 & 33,3 & 123,3 & 25,1 & 104,8 \\
\hline $\begin{array}{l}\text { Консервы мясные, } \\
\text { т[ыс.] у[словных] } \\
\text { б[анок] }\end{array}$ & 5348 & 7974 & 149,1 & 5226 & 101,0 \\
\hline $\begin{array}{l}\text { Мясные } \\
\text { полуфабрикаты, } \\
\text { тыс. тонн }\end{array}$ & $\ldots$ & $\ldots$ & $\ldots$ & 11,4 & 97,1 \\
\hline
\end{tabular}


За 3 года и 8 месяцев текущей пятилетки произошел рост выработки мяса, колбасных изделий, консервов мясных. Произведено сверх плана 16 тысяч тонн мяса и субпродуктов, 3 тысячи тонн колбасных изделий, 0,7 миллиона условных банок мясных консервов.

Снижается производство мясных полуфабрикатов, несмотря на рост выработки мяса. Медленно расширяется ассортимент мясной продукции. Решением облисполкома № 407 от 22.08.88 г. предусмотрено производство новых видов продуктов питания, в том числе довести производство полуфабрикатов и кулинарных изделий из мяса птицы в 1990 году до 980 тонн.

За первое полугодие текущего года их произведено 454 тонны. Это позволяет предполагать, что задание будет выполнено.

B I полугодии т[екущего] г[ода] по сравнению с соответствующим периодом прошлого года в промышленности облагропрома выработка продукции с одной тонны переработанного скота и птицы увеличилась на 2 процента. Однако еще допускаются потери из-за отсутствия должного контроля за выходом мяса и мясопродуктов в соответствии с установленными нормами. На предприятиях не обеспечивается полный сбор субпродуктов I и II категории, жира-сырца и других видов сырья. Так, на Новосибирском мясоконсервном комбинате за 6 месяцев т.г. было недополучено против установленных норм 80 тонн субпродуктов, на Чановском мясокомбинате - 28 тонн субпродуктов и 7 тонн жира-сырца, на Купинском мясокомбинате - 17 тонн субпродуктов.

В промышленности области имеются резервы для увеличения выпуска мясной продукции за счет своевременного освоения проектных и более полного использования действующих производственных мощностей, улучшения качества выпускаемой продукции.

За три года текущей пятилетки почти не выросли мощности по производству мясной продукции, за исключением мощностей по выработке мяса:

\begin{tabular}{|l|c|c|c|}
\hline \multirow{2}{*}{} & \multicolumn{2}{|c|}{ На 1 января } & \multirow{2}{*}{$\begin{array}{c}\text { Прирост (+), } \\
\text { снижение (-) } \\
\text { за 3 года, в \% }\end{array}$} \\
\cline { 2 - 3 } & 1986 г. & 1989 г. & $+21,0$ \\
\hline Мясо, тонн в смену & 421,7 & 510,4 & $+3,8$ \\
\hline Колбасные изделия, тонн в смену & 65,7 & 68,2 & - \\
\hline Полуервы мясные, т[ыс.] у[словных] б[анок] в смену & 36,0 & 36,0 & $-0,7$ \\
\hline
\end{tabular}

*1987 г.

Уровень использования производственных мощностей за этот период существенно не изменился и составил в 1988 году по выработке мяса 71,4 процента, мясных полуфабрикатов - 88,7, консервов мясных - 51,6, колбасных изделий - 91,2.

При полном использовании имеющихся мощностей только за 1988 год можно было бы дополнительно произвести 47,2 тысячи тонн мяса, 3,0 тысячи тонн колбасных изделий.

C отставанием от установленных сроков осваиваются проектные мощности по производству мяса Новосибирским мясоконсервным комбинатом. Здесь мощности, реконструированные в 1987 году (176 тонн мяса в смену), в 1988 году освоены лишь на 5 процентов к проекту, хотя срок их освоения истек.

На предприятиях облагропрома продолжает иметь место выпуск некачественной продукции. За 1988 год и 8 месяцев 1989 года Западно-Сибирским центром стандартизации и метрологии было забраковано 20 тонн колбасных изделий $(35,7 \%$ к проверенному количеству), 13 тонн мяса птицы (25,6 \%).

Низкого качества вырабатывалось мясо птицы на Октябрьском птицекомбинате. Только при одной проверке было забраковано 100 процентов проверенного количества мяса цыплят-бройлеров.

На ряде предприятий допускался выпуск колбасных изделий низкого качества. Так, на Новосибирском и Куйбышевском мясокомбинатах браковалось до 100 процентов проверенного количества продукции одного наименования. 
На предприятиях потребительской кооперации также имеются факты выпуска некачественной продукции. Полностью браковалось проверенное количество колбасных изделий отдельных сортов в объединении общественного питания Карасукского рай[онного]П[отребительского]О[бщества], на Краснозерском производственном комбинате, в объединении промышленности Купинского рай[онного]П[отребительского]О[бщества].

За период с 1985 года по 1988 год поставка мяса и мясопродуктов по рыночному фонду из государственных ресурсов возросла на 14 процентов и составила в 1988 году 96,5 тысячи тонн.

В расчете на одного жителя приходилось мяса из государственных ресурсов 34,5 килограмма против 30,8 в 1985 году.

Объемы поставки в торговле мяса и мясопродуктов из государственных ресурсов изменились следующим образом:

\begin{tabular}{|l|c|c|c|c|c|c|}
\hline & 1985 г. & 1986 г. & 1987 г. & 1988 г. & \multicolumn{2}{|c|}{1988 г. в \% к } \\
\cline { 4 - 7 } & & & & & 1985 г. & 1987 г. \\
\hline $\begin{array}{l}\text { Мясо и мясопродукты в пересчете } \\
\text { на мясо - тыс. тонн }\end{array}$ & 84,5 & 82,7 & 87,8 & 96,5 & 114 & 110 \\
\hline в том числе: & & & & & & 115 \\
\hline мясо - тыс. тонн & 54,6 & 50,9 & 57,2 & 62,9 & 110 \\
\hline колбасные изделия - тыс. тонн & 16,8 & 18,0 & 18,4 & 20,4 & 121 & 111 \\
\hline $\begin{array}{l}\text { мясные консервы - т[ыс.] } \\
\text { у[словных] б[анок] }\end{array}$ & 2088 & 3191 & 2311 & 4035 & в 1,9 р. & в 1,7 р. \\
\hline $\begin{array}{l}\text { мясорастительные - т[ыс.] } \\
\text { у[словных] б[анок] }\end{array}$ & 518 & 1428 & 497 & 1012 & в 1,9 р. & в 2 р. \\
\hline котлеты - тыс. тонн & $76,2^{*}$ & $82,8^{*}$ & 3,8 & 3,4 & $\ldots$ & 89 \\
\hline пельмени - тыс. тонн & 4,8 & 4,2 & 4,3 & 4,0 & 83 & 93 \\
\hline
\end{tabular}

* в тысячах штук

Спрос населения на мясо и мясопродукты удовлетворяется не полностью. Торговля ими осуществляется по установленным месячным лимитам, с применением талонов.

Поставка мяса и мясопродуктов по рыночному фонду составила в 1988 году 61 процент фонда потребления.

Фонд потребления населением мяса и мясных продуктов в 1988 году составил 205,5 тысячи тонн. По сравнению с 1985 годом он увеличился на 18,6 тысячи тонн, или 10 процентов, что видно из следующих данных:

\begin{tabular}{|l|c|c|c|c|c|}
\hline & 1985 г. & 1986 г. & 1987 г. & 1988 г. & 1988 г. в \% к 1985 г. \\
\hline Тысяч тонн & 186,9 & 182,8 & 197,2 & 205,5 & 110 \\
\hline
\end{tabular}

Потребление мяса и мясных продуктов обеспечивается их производством в области. Объем производства мяса в 1988 году составил 223,2, фонд потребления - 205,5 тысячи тонн.

На душу населения в 1988 году было потреблено 74 килограмма мяса и мясных продуктов, что на 6 килограммов больше, чем было потреблено в 1985 году.

В области в последние годы возросло производство мяса и мясных продуктов. Улучшается самообеспечение мясом сельского населения. Получают дальнейшее развитие подсобные сельские хозяйства предприятий, учреждений и организаций.

Вместе с тем имеются трудности в снабжении населения этими продуктами питания. Остаются неиспользованными существенные резервы интенсификации животноводства. Хозяйства несут большие потери мяса от падежа животных (в 1988 году - около 39 тысяч 
тонн), яловости маточного поголовья (около 19 тысяч тонн). При переработке мяса допускаются значительные потери мяса и мясопродуктов, выпускается большое количество продукции низкого качества.

Зам. начальника областного управления статистики А.А. Антропов

ГАНО. Ф. Р-11. Оп. 9. Д. 868. Л. 111-126. Подлинник. Машинопись, дублетный экземпляр, напечатано под копирку, адресаты вписаны от руки. Подпись - автограф. На л. 111 - типографский угловой штамп Новосибирского областного управления статистики с номером (09-23) и датой (30.11.89 г.) регистрации документа.

\section{КОММЕНТАРИИ}

${ }^{1}$ Муха В.П. - первый секретарь Новосибирского обкома КПСС.

2 Боков В.А - председатель Новосибирского облисполкома.

${ }^{3}$ Продовольственная программа СССР - государственная программа, принятая в СССР на майском (1982 г.) Пленуме ЦК КПСС для преодоления товарного дефицита в стране. Программа, принятая на период 19821990 гг., должна была интенсифицировать производство в сфере сельского хозяйства и улучшить ситуацию с продовольственным снабжением в СССР (КПСС в резолюциях и решениях съездов, конференций и пленумов ЦК. 9-е изд. М., 1987. Т. 14. С. 276-314).

${ }^{4}$ Яловость - это явление, когда животное в один сезон не произвело на свет потомство, т.е. у него не произошло плодотворное осеменение.

${ }^{5}$ Подсобные хозяйства предприятий и учреждений - специализирующиеся на производстве сельхозпродуктов структурные подразделения промышленных предприятий или учреждений. Их продукция предназначается для снабжения работников основного производства. В периоды наибольшего развития играли важную роль в продовольственном обеспечении жителей города. Могли располагаться как на территории предприятия или учреждения, так и в пригородной зоне. Размеры варьировались от небольших свинарников или теплиц до крупных многоотраслевых сельхозпредприятий (Букин С.С., Ильиных В.А. Подсобные хозяйства предприятий и учреждений // Энциклопедия Новосибирск. Новосибирск, 2003. С. 679).

\section{Лumepamypa}

Букин С.С., Ильиных В.А. Подсобные хозяйства предприятий и учреждений // Энциклопедия Новосибирск. Новосибирск: Новосиб. кн. изд-во, 2003. С. 679-680.

КПСС в резолюциях и решениях съездов, конференций и пленумов ЦК. 9-е изд. М.: Политиздат, 1987. Т. 14. 638 с.

Крестьянство и сельское хозяйство Сибири. 1960-1980-е гг.: кол. моногр. / отв. ред. Н.Я. Гущин. Новосибирск: Наука. Сиб. отд-ние, 1991. 493 с.

\section{References}

Bukin, S.S, Il'inykh, V.A. (2003). Podsobnye hozyaistva predpriyatiy i uchrezhdeniy [Subsidiary farms of enterprises and institutions]. In Enciklopediya Novosibirsk. Novosibirsk, Novosibirskoe knizhnoe izdatel'stvo, pp. 679-680.

Gushchin, N.Ya. (Ed.). (1991). Krest'yanstvo i sel'skoe hozyajstvo Sibiri. 1960-1980-e gg. [Siberian Peasantryand Agriculture. 1960s-1980s.]. Novosibirsk, Nauka, Sibirskoe otdelenie. 493 p.

KPSS v rezolyuciyah i resheniyah s'ezdov, konferencij i plenumov TSK [CPSU in Resolutions and Decisions of Congresses, Conferences and Plenums]. (1987). 9-e izdanie. Moscow, Politizdat. Vol. 14. 639 p. 